\title{
Radionuclides Content in Tissues and Organs of Pumpkinseed Lepomis Gibbosus (Linnaeus, 1758) from the Zaporizhzhia (Dnipro) Reservoir
}

\author{
O.M. Marenkov*, O.S. Nesterenko
}

Scientific Research Laboratory of Hydrobiology, Ichthyology and Radiobiology of the Scientific Research Institute of Biology of the Oles Honchar Dnipro National University, Dnipro, Ukraine

*Corresponding author: gidrobions@gmail.com

Keywords: pumpkinseed, Lepomis gibbosus, radioecology, radionuclides, Dnipro, Zaporizhzhia (Dnipro) reservoir

Abstract. The article presents the results of studies on the content of artificial $\left({ }^{137} \mathrm{Cs},{ }^{90} \mathrm{Sr}\right)$ and natural radionuclides $\left({ }^{226} \mathrm{Ra},{ }^{232} \mathrm{Th},{ }^{40} \mathrm{~K}\right)$ in tissues and organs of various individuals of pumpkinseed Lepomis gibbosus (Linnaeus, 1758) from the Zaporizhzhia (Dnipro) reservoir. It has been revealed that in the bones of sexually mature pumpkinseed females, the content of radionuclides ${ }^{137} \mathrm{Cs}$ and ${ }^{90} \mathrm{Sr}$ is $24.7 \%$ and $28.6 \%$ less, respectively, than in the bones of males. Summing up the materials of radioecological studies of 2017-2018, the following sequence of tissues and organs of the pumpkinseed by the ability to accumulate radionuclides was obtained: bone $>$ muscle $>$ scales $>$ gills. Research results can be useful for further study on the fish radiation load in the basins of the Dnipro River and during monitoring radioecological research. It was determined that the content of radionuclides in the pumpkinseed muscles did not exceed the permissible levels of radionuclide content for fish as a food product (permissible levels of radionuclide content for ${ }^{137} \mathrm{Cs}-150 \mathrm{~Bq} / \mathrm{kg}$, $\left.{ }^{90} \mathrm{Sr}-35 \mathrm{~Bq} / \mathrm{kg}\right)$.

\section{Introduction}

By 2018, there are 21 uranium deposits in Ukraine; most of them are located in the Dnipropetrovsk region [1]. In the Pridneprovsk region, enterprises on the extraction and primary processing of uranium ores are concentrated, as well as tailing dumps of radioactive waste, which are powerful sources of radiation impact on the water environment [2]. Radioecological situation has significantly deteriorated because of the Chernobyl accident, after which in 1986, artificial high-toxic radionuclides such as ${ }^{137} \mathrm{Cs}$ and ${ }^{90} \mathrm{Sr}$ got into the Dnipro basin $[1,3,4,5]$. Along with other anthropogenic pollutants, they have caused the occurrence of a difficult radioecological situation in the Zaporizhzhia (Dnipro) reservoir and fish can accumulate them [2].

The urgency of studying the radionuclides accumulation and their distribution in the alien fish from reservoirs with different levels of radionuclide pollution is caused by the fact that such studies allow estimating the process of accumulation of radionuclides in fish [6, 7] that are in the new existence conditions and tracing the routes of toxicants migration in aquatic ecosystems.

The high level of environmental pollution by toxicants leads to a decrease in the hydrobionts species diversity. Therefore, using hydrobionts as bioindicators helps determining the influence and significance of toxic substances. Many groups of hydrobionts are studied as indicators of aquatic toxicity: plants and animals (fish, crustaceans, mollusks, polychaetes, etc.) $[1,4,6,8]$

Pumpkinseed Lepomis gibbosus (1758) is a member of the sunfish (Centrarchidae) family, perciformes (Perciformes) order. Today, the pumpkinseed is one of the most common alien species in the Zaporizhzhia (Dnipro) reservoir basin, which rapidly increases its number and biomass [9]. In Zaporizhzhia (Dnipro) reservoir the species began to be found massively in 2002, and since 2017 it appeared in the heat sink of the Zaporizhzhya NPP [10], indicating the rapid spread of this species in all types of reservoirs $[11,12]$, including natural to technical reservoirs with different degrees of radioactive loading. The pumpkinseed is an invasive species that has recently entered the water bodies of Ukraine (30 years ago). We study the accumulation of radionuclides in the tissues of this species in the context of a comprehensive approach to investigate its adaptive capacity in Zaporizhzhya reservoir conditions. 
In this regard, the purpose of our work was to determine the levels of radionuclide content of natural $\left({ }^{40} \mathrm{~K},{ }^{226} \mathrm{Ra},{ }^{232} \mathrm{Th}\right)$ and artificial $\left({ }^{137} \mathrm{Cs}\right.$ and $\left.{ }^{90} \mathrm{Sr}\right)$ origin in the tissues and organs of the pumpkinseed, Lepomis gibbosus (Linnaeus, 1758).

\section{Materials and Methods}

The object of the study were sexually mature pumpkinseed Lepomis gibbosus (Linnaeus, 1758) individuals, aged 4+ (five summers old). One hundred specimens of females and one hundred specimens of males were used for research. The material for work were muscles, bones, gills and scales collected during scientific research in June 2017-2018. The ichthyological sampling was carried out in the Samara Bay of the Zaporizhzhia (Dnipro) reservoir. The fish were caught at two observation points located in the Samara Bay (Odynkivka village $48.50602 \mathrm{~N}, 35.18871$ E, Novoselivka village 48.57354 N, 35.23509 E). The biological analysis of fish and the selection of tissues and organs were carried out in accordance with the classical hydrobiological and radiobiological methods $[8,13,14]$. The samples for measuring the content of radionuclides were prepared by separating fish tissues with subsequent homogenization and concentration (drying) of the selected material. Samples were dried at $105^{\circ} \mathrm{C}$ to a constant dry mass. To determine the activity of ${ }^{137} \mathrm{Cs},{ }^{226} \mathrm{Ra},{ }^{232} \mathrm{Th}$ it was used dry tissues with weighed $100 \mathrm{~g}$, and to determine the activity of ${ }^{90} \mathrm{Sr}$ and ${ }^{40} \mathrm{~K}-200 \mathrm{~g}$. Coefficients of drying of fish tissues: for muscle -4.7 , for bone 3.7 , for scales -2.7 , for gills -4.6 .

The radionuclides were determined on a scintillationgamma-ray spectrometer SEG-001 "ACP-C" and a beta-radiation spectrometer SEB-01-150 in a certified laboratory of the sanitaryepidemiologicalstation. To measure the activity of radionuclides, we used samples of dry tissue - at least 10 grams each. The values of the minimum detected activity for radionuclides are: ${ }^{137} \mathrm{Cs}-$ over 3.6 Bq/sample, ${ }^{90} \mathrm{Sr}$ - over $2.4 \mathrm{~Bq} / \mathrm{sample},{ }^{40} \mathrm{~K}$ - over $4.5 \mathrm{~Bq} / \mathrm{sample},{ }^{232} \mathrm{Th}-$ over $3.0 \mathrm{~Bq} / \mathrm{sample}$, ${ }^{226} \mathrm{Ra}$ - over $6.0 \mathrm{~Bq} / \mathrm{sample}$. The activity of radionuclides was calculated in $\mathrm{Bq} / \mathrm{kg}$ of wet weight $[14,15]$. Selection of water, preparation of samples for analysis and determination of the content of radionuclides in water were carried out due to the generally accepted methods: we have evaporated 40 liters of water to a volume of $1: 1[8,14,15]$.

Statistical data processing was carried out by generally accepted methods using the software package Statistica 8.0 (StatSoft Inc., USA). All results are given as the mean value \pm standard deviation (SD).

\section{Results and Discussion}

The content of radionuclides by the parameters of total $\beta$-activity in water of the Zaporizhzhia (Dnipro) reservoir was within the range of $0.13-0.29 \mathrm{~Bq} / \mathrm{dm}^{3}$, strontium-90 $-0.025-0.1 \mathrm{~Bq} / \mathrm{dm}^{3}$, cesium-137 - 0.06-0.74 Bq/ $\mathrm{dm}^{3}$. An ecological assessment of the surface waters quality in Ukraine has been carried out on the criteria of specific indicators of radiation impact. It has been established that according to the content by the concentration of strontium-90, cesium-137 in water, as well as by the indicators of total $\beta$-activity, the water of the Zaporizhzhia (Dnipro) reservoir is characterized as a very clean to slightly polluted. The largest indicators of radioactive contamination are noted in the water of the upper part of the Zaporizhzhia (Dnipro) reservoir, which is due to the inflow of contaminated water from higher reservoirs. In suspended particles, the highest rates are noted in places of intense phytoplankton growth.

During the study period, the largest amount of artificial radionuclides in tissues and organs of the pumpkinseed from Samara Bay was detected in the fish bones: the content of ${ }^{137} \mathrm{Cs}$ was $8.3 \pm 0.7 \mathrm{~Bq} / \mathrm{kg},{ }^{90} \mathrm{Sr}-5.1 \pm 0.4 \mathrm{~Bq} / \mathrm{kg}$ (Fig. 1). As compared to other tissues, the content of strontium in the bones of pumpkinseed was the highest, which is primarily caused by the biological ability of fish bone tissue to accumulate it, as an analogue of calcium [6]. 


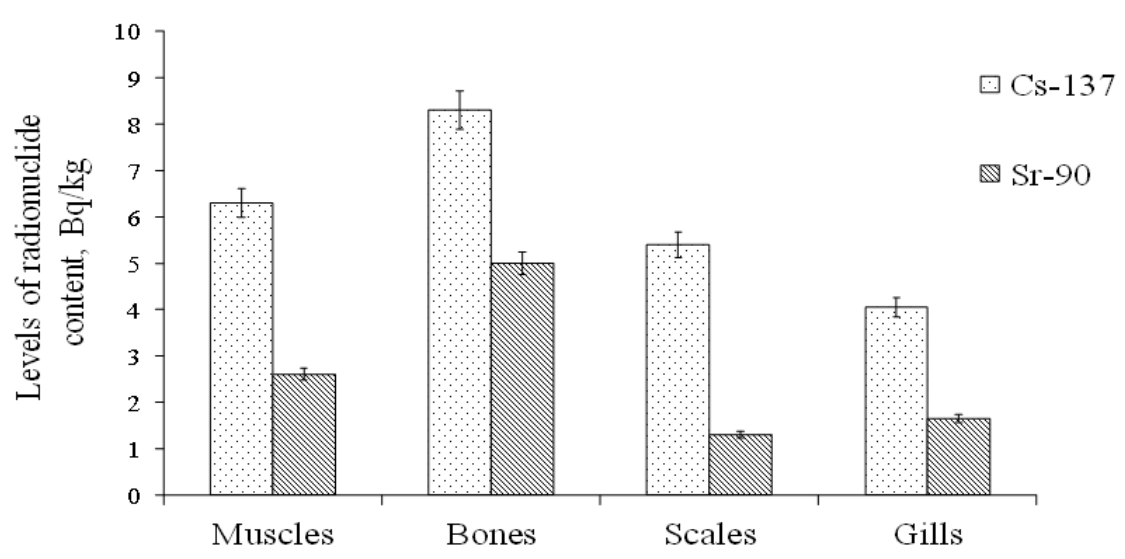

Figure 1. Levels of artificial radionuclides accumulation in tissues and organs of pumpkinseed individuals of both sexes, 2017.

After entering the fish organism, soluble strontium compounds are selectively accumulated in the bones. ${ }^{90} \mathrm{Sr}$ accumulated in the bone tissue remains there for a long time, constantly irradiating the tissues, resulting in pathological changes in the bone tissue, which occur much more frequent than in other organs and tissues of the body [6].

The process of the radionuclides accumulation in the pumpkinseed, as well as other species of fish, begins when larvae starts the active nutrition [6]. With low content of radioactive substances in water, their intake into the body of the pumpkinseed is due to contaminated fodder objects.

Investigations of different pumpkinseed individuals in 2018 showed that in the bones of females, the content of radionuclides ${ }^{137} \mathrm{Cs}$ and ${ }^{90} \mathrm{Sr}$ was $24.7 \%$ and $28.6 \%$ less, respectively, than in the bones of males (Fig. 2). Such difference in the radionuclides accumulation between males and females is due to maturation of pumpkinseed gametes, namely the radionuclides accumulation in eggs during maturation of gametes.

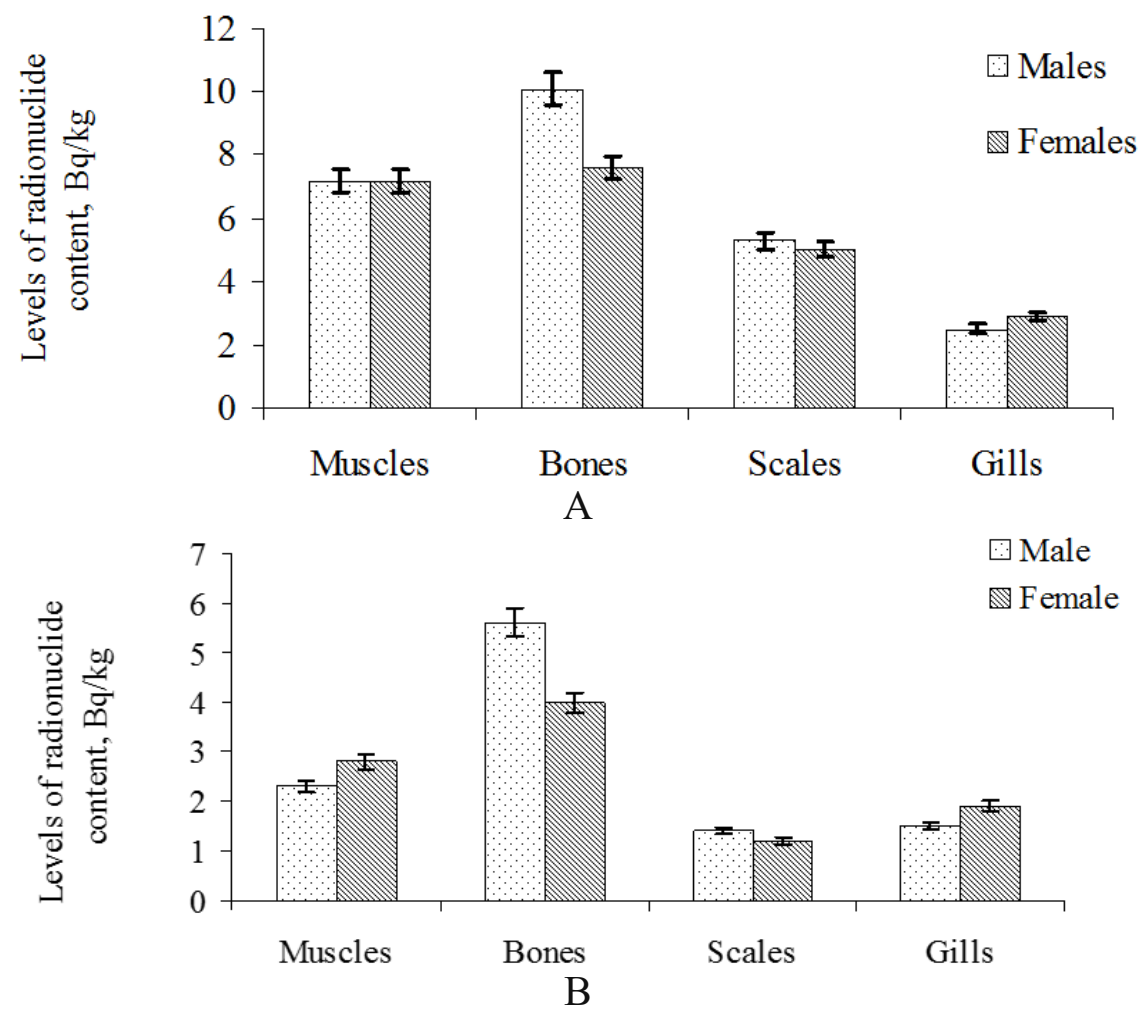

Figure 2. Levels of artificial radionuclides accumulation in tissues and organs of different pumpkinseed individuals, 2018: $\mathrm{A}-{ }^{137} \mathrm{Cs}, \mathrm{B}-{ }^{90} \mathrm{Sr}$.

Among the investigated organs during the two experimental years, the lowest content of radionuclides was observed in the gills of the pumpkinseed: ${ }^{137} \mathrm{Cs}-2.9-4.1 \mathrm{~Bq} / \mathrm{kg} ;{ }^{90} \mathrm{Sr}-1.5-$ 
1.7 Bq/kg (Fig. 1, 2). There was no difference between the accumulation of radionuclides in the gills of pumpkinseed females and males. ${ }^{90} \mathrm{Sr}$ enters into the body of fish through the gills, and ${ }^{137} \mathrm{Cs}$ enters with food. The smallest content of radionuclides in gills can be explained by the fact that fish gills are constantly in contact with the aquatic environment and are often washed with water. In addition, gills carry out the excretory function, therefore, due to the functioning of chloride cells of the gill apparatus, radionuclides are rapidly removed (or deposited slower) by the gill epithelium [6].

Despite the fact that the pumpkinseed is a rather small fish without industrial and nutritional value in Ukraine, this fish is used for fishing. Consumer use of the pumpkinseed is based on significant volumes of its industrial catch; in the summer in the Samara Bay, daily fishermen catches in the fish catch point of Novoselivka village during the period from 10 June to 10 July can reach 150-200 kg/day [15]. Due to this consumer use of the pumpkinseed there is an urgent issue of studying the content of radionuclides in the fish muscle tissue as the main source of radionuclides intake from the food chain from fish to the human body. In the pumpkinseed muscles, the levels of artificial radionuclides were: ${ }^{137} \mathrm{Cs}-6.9 \pm 0.4 \mathrm{~Bq} / \mathrm{kg},{ }^{90} \mathrm{Sr}-2.6 \pm 0.3 \mathrm{~Bq} / \mathrm{kg}$. Among the investigated artificial radionuclides, in muscle tissue cesium-137 accumulated most of all, due to the physiological activity of muscle fibers and the fact that cesium-137 is a chemical analogue of potassium, which is actively involved in the work of fish muscles [6]. A similar pattern of high content of cesium over the content of strontium in the fish muscle tissue is common for many freshwater fish species. The largest content of ${ }^{137} \mathrm{Cs}$ in muscle tissue of males and females was in 2018 and amounted to $7.2 \pm 0.2 \mathrm{~Bq} / \mathrm{kg}$. During the investigated period, the difference between the accumulation of artificial radionuclides in the muscles of pumpkinseed males and females was not noticed. It was determined that the content of radionuclides in the pumpkinseed muscles did not exceed the permissible levels of radionuclide content for fish as a food product (permissible levels of radionuclide content for ${ }^{137} \mathrm{Cs}-150 \mathrm{~Bq} / \mathrm{kg},{ }^{90} \mathrm{Sr}-35 \mathrm{~Bq} / \mathrm{kg}$ ) $[16,17]$.

Fish scales have a protective boundary function and have low metabolic process, since its main function is mechanical and protective. Moreover, mucus on the surface of the scale of the pumpkinseed, binds toxic and radioactive substances, protecting the body of fish [6, 18]. During the study period, the amount of radionuclides in the scales of the pumpkinseed was following: 2017: ${ }^{137} \mathrm{Cs}-5.4 \pm 0.2 \mathrm{~Bq} / \mathrm{kg},{ }^{90} \mathrm{Sr}-1.3 \pm 0.1 \mathrm{~Bq} / \mathrm{kg} ; 2018:{ }^{137} \mathrm{Cs}-5.2 \pm 0.3 \mathrm{~Bq} / \mathrm{kg},{ }^{90} \mathrm{Sr}-1.3 \pm 0.2 \mathrm{~Bq} / \mathrm{kg}$. There was no between the radionuclides accumulation in scales of pumpkinseed males and females.

For natural radionuclides the following sequences of their distribution in the pumpkinseed tissues and organs were determined (Fig. 3, 4):

${ }^{40} \mathrm{~K}$ - muscles $(105.1-127.2 \mathrm{~Bq} / \mathrm{kg})>$ bones $(71.6-107.1 \mathrm{~Bq} / \mathrm{kg})>$ scales $(96.4-102.2 \mathrm{~Bq} / \mathrm{kg})$ $>$ gills $(54.9-85.75 \mathrm{~Bq} / \mathrm{kg})$;

${ }^{232} \mathrm{Th}-$ bones $(59.8-70.1 \mathrm{~Bq} / \mathrm{kg})>$ gills $(35.3-47.1 \mathrm{~Bq} / \mathrm{kg})>\operatorname{scales}(13.1-23.9 \mathrm{~Bq} / \mathrm{kg})>$ muscles $(10.5-21.4 \mathrm{~Bq} / \mathrm{kg})$;

${ }^{226} \mathrm{Ra}$ - bone $(32.4-45.9 \mathrm{~Bq} / \mathrm{kg})>$ muscles $(27.4-40.3 \mathrm{~Bq} / \mathrm{kg})>$ scales $(34.7-40.2 \mathrm{~Bq} / \mathrm{kg})>$ gills $(27.6-35.4 \mathrm{~Bq} / \mathrm{kg})$.

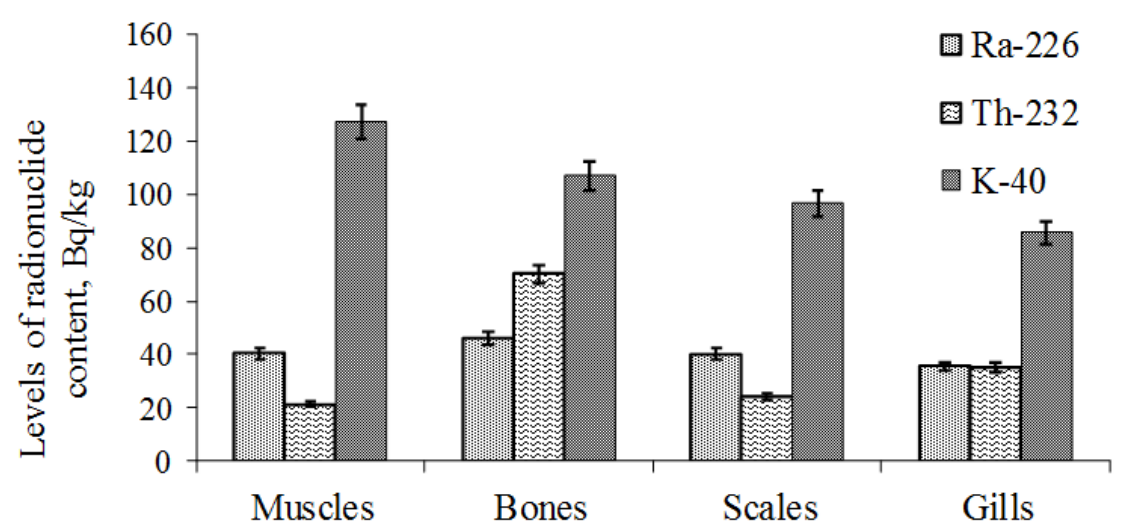

Figure 3. Levels of accumulation of radionuclides of natural origin in tissues and organs of the pumpkinseed, 2017. 

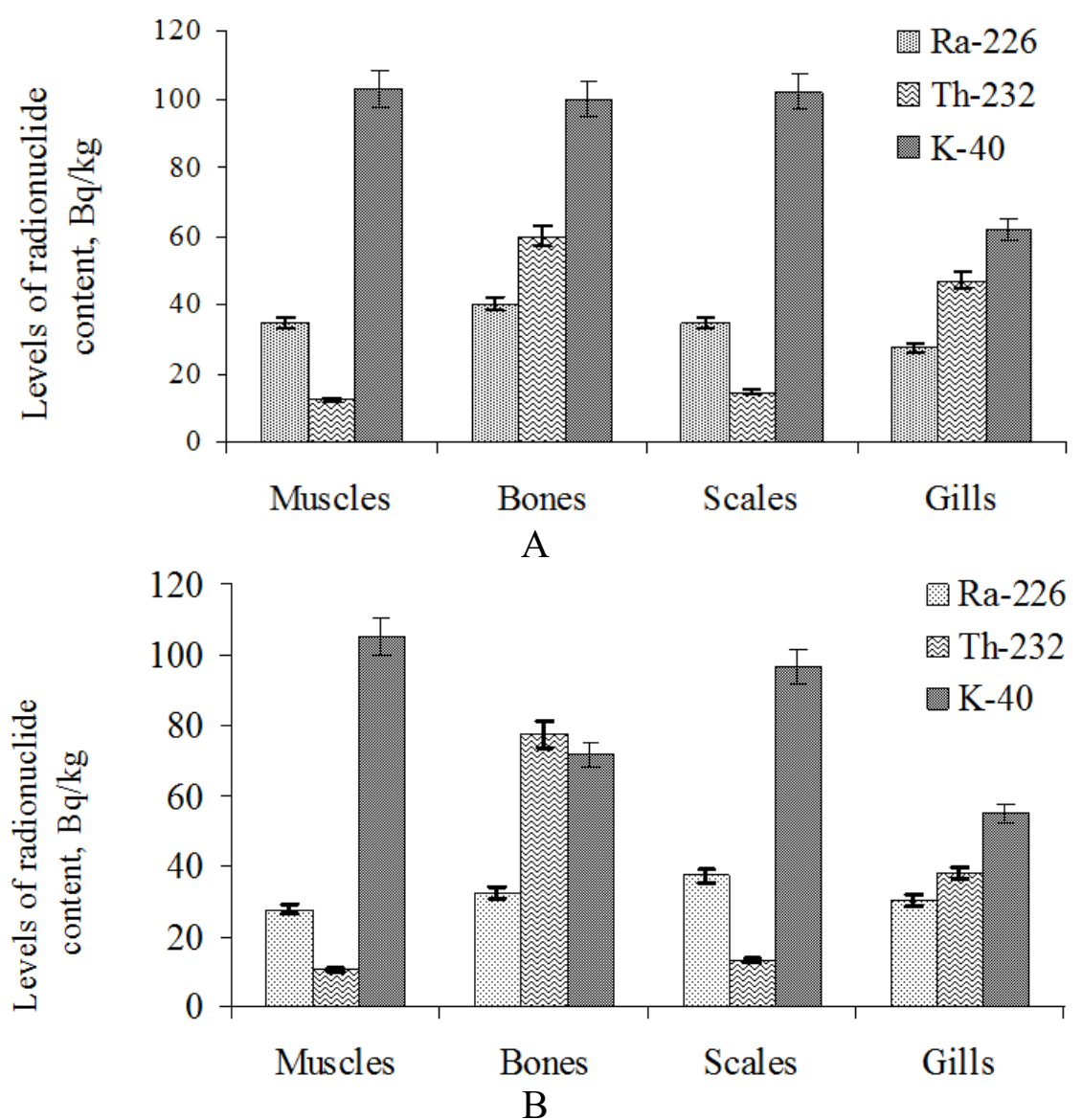

Figure 4. Levels of natural radionuclides accumulation in tissues and organs of different pumpkinseed individuals, 2018: A - males, B - females.

The highest content of potassium- $40\left({ }^{40} \mathrm{~K}\right)$ in muscles is caused by its biological activity in transmembrane transport mechanisms. The greatest amount of strontium-90, thorium-232 and radium-226 in the bones of pumpkinseed males and females is due to the chemical nature of radionuclides and the structure of bone tissue. Bones have a rather slow physiological exchange and deposit the necessary trace elements or their chemical analogues in the intercellular substance. Since these radionuclides appear to be chemical analogues of some trace elements, they bind to the bone tissue and remain in it for a long time. Such concentration of radioactive substances impacts negatively the fish organism, as there is a chronic internal radioactive exposure of the organism. Somewhat less radionuclides were deposited in the muscles of the pumpkinseed, because of their fast metabolism. Less radionuclides were in the fish scales, because they act as a protective boundary and have a rather low metabolic process, performing musculoskeletal and barrier functions. The smallest amount of radionuclides was in the gills of fish, because their metabolic process is fast for performing a respiratory and excretory function [6].

\section{Conclusions}

1. The largest amount of artificial radionuclides in the tissues and organs of pumpkinseed, caught in the Samara Bay of the Zaporizhzhia (Dnipro) reservoir was revealed in the fish bones: the content of cesium-137 was $8.3 \pm 0.7 \mathrm{~Bq} / \mathrm{kg}$, strontium- 90 was $5.1 \pm 0.4 \mathrm{~Bq} / \mathrm{kg}$. As compared to other tissues, the content of strontium-90 in the bones was the highest, which is caused by the biological ability of fish bone tissue to accumulate it, as a biological analogue of calcium. The lowest content of radionuclides was in scales and gills of the pumpkinseed.

2. It was indicated that in the bones of sexually mature pumpkinseed females, the content of radionuclides ${ }^{137} \mathrm{Cs}$ and ${ }^{90} \mathrm{Sr}$ is $24.7 \%$ and $28.6 \%$ less, respectively, than in the bones of males. This is due to the maturation of the pumpkinseed eggs, namely the radionuclides accumulation by the gonads of females during the formation of sexual products. 
3. Among the natural radionuclides, ${ }^{40} \mathrm{~K}$ had the highest content; it was deposited in the muscles and reached 105.1-127.2 Bq/kg. For natural radionuclides, the following trend for radionuclide content has been observed: the highest content was in the bones, less in the muscles, even less in the scales, and the lowest one was in the gills.

4. Summing up the materials of two years, the following sequence of tissues and organs of the pumpkinseed by the ability to accumulate radionuclides was made: bone $>$ muscle $>$ scales $>$ gills. This sequence is common for the pumpkinseed individuals of both sexes.

5. Although the pumpkinseed since 2017 has been included into the list of industrial fish species of the Zaporizhzhia (Dnipro) reservoir, it is still not industrially valuable. Taking into account the nutritional value of this species, it was determined that the content of the studied radionuclides in the pumpkinseed tissues and organs in the Zaporizhzhia (Dnipro) reservoir did not exceed the permissible levels of radionuclide content for fish as a food product.

\section{References}

[1] A.S. Bilokon. Accumulation of radionuclides in industrial species of fish of the Dnipro reservoir. Fish Farming 66 (2009) 230. (in Ukrainian)

[2] A.S. Belokon, O.N. Marenkov, A.I. Dvoretskij. Contents of radionuclides and heavy metals in fish roe of commercial fish of the Zaporizhya reservoir. Yaderna Fizyka ta Energetyka (Nucl. Phys. At. Energy) 14(1) (2013) 82. (in Russian)

[3] B.S. Prister, N.A. Loshchilov, O.F. Nemets, V.A. Poyarkov. Fundamentals of Agricultural Radiology. 2-nd ed. (Kyiv: Urozhaj, 1991) 472 p. (in Russian)

[4] O.M. Volkova, V.V. Belyaev, O.E. Kahlyan. Method of estimation of the radioecological state of aquatic ecosystems in the content of radionuclides in hydrobionts. Natural almanac. Biological sciences 8 (Kherson: PP Vishemirsky, 2006) 12. (in Ukrainian)

[5] M.S. Meixler, M.B. Bain. Predicting ecological outcomes of stream creation using fish community attributes. Ecological engineering 37(9) (2011) 1422.

[6] I.A. Shehanova. Radioecology of fish (Moscow: Legaya i pishchevaya promyshlennost, 1983) 208 p. (in Russian)

[7] E.N. Volkova, V.V. Belyaev, O.L. Zarubin, Z.O. Shirokaya, A.E. Kaglin. Dynamics of ${ }^{137}$ Cs in the hydrobionts of the Dnieper reservoirs. Scientific notes of Ternopil National Pedagogical University named after Volodymyr Hnatyuk. Series: Biology 3(26) (2005) 70. (in Russian)

[8] Methods of Hydroecological Surveys of Surface Waters. Ed. V. D. Romanenko (Kyiv: LOGOS, 2006) 408 p. (in Ukrainian)

[9] E.V. Fedonenko, O. N. Marenkov. Spreading, spatial distribution, and morphometric characteristics of the pumpkinseed sunfish Lepomis gibbosus (Centrarchidae, Perciformes) in the Zaporozhye Reservoir. Russian journal of biological invasions 4(3) (2013) 196.

[10] O. Marenkov. Ichthyofauna of the Zaporizhia Nuclear Power Plant cooling pond (Enerhodar, Ukraine) and its biomeliorative significance. Ukrainian Journal of Ecology, 8(2) (2018) 140.

[11] M. H. Paller, D. E. Fletcher, M. M. Standora, T. B. Grabowski, T. A. Jones, S. A. Dyer, J. J. Isely. Emigration of fish from two South Carolina cooling reservoirs. North American Journal of Fisheries Management 26(4) (2006) 978.

[12] O. Marenkov, O. Nesterenko. Estimation of physiological and biological indices and consequences of biological invasion of the pumpkinseed Lepomis gibbosus (Linnaeus, 1758) in the Zaporizke Reservoir, Ukraine. World Scientific News, 95 (2018) 27.

[13] Methods for fish biology. Ed. by Carl B. Schreck and Peter B. Moyle. (Bethesda, Maryland, USA, 1990) $685 \mathrm{p}$. 
[14] Methods of sampling agricultural products and foodstuffs for laboratory analysis of the content of radionuclides. Directory for Radiological Services of the Ministry of Agriculture and Food of Ukraine (Kiev, 1997) 14 p. (in Ukrainian)

[15] V.V. Babenko, O.S. Kazimirov, O.F. Ruddyk Activity of beta-radiation radionuclides in counting samples. Method of measuring performance using scintillation spectrometers and software AK-1 (Kiev: NPP Atom Complex Instrument, 1998) 27 p. (in Ukrainian)

[16] Norms of radiation safety of Ukraine (NRBU-97). State Hygiene Standards. (Kyiv: Department of Polygraphy of the Ukrainian Center for State Surveillance of the Ministry of Health of Ukraine, 1997) 121 p. (in Ukrainian)

[17] Permissible levels of radionuclide content ${ }^{137} \mathrm{Cs}$ and ${ }^{90} \mathrm{Sr}$ in food and drinking water. State Hygiene Standards. Official Bulletin of Ukraine, 29 (2006)142. (in Ukrainian)

[18] V.M. Kozak, V.V. Brygadyrenko. Impact of cadmium and lead on Megaphyllum kievense (Diplopoda, Julidae) in a laboratory experiment. Biosystems Diversity, 26(2) (2018) 128-131. http://doi.org/10.15421/011820 